\title{
WIRAUSAHA ITU MENGUNTUNGKAN DAN MENYENANGKAN PELATIHAN DI JALAN MASJID AL HUKAMA RANGKAPAN JAYA BARU PANCORAN MAS, DEPOK
}

\author{
Endang Susilo Wardani ${ }^{1)}$, Oki Iqbal Khair ${ }^{2)}$, Reza Octovian ${ }^{3)}$, Diana Riyana ${ }^{4}$, \\ Nelwati Tanius ${ }^{5}$ \\ 1,2,3,4,5Program Studi Manajemen S1, Fakultas Ekonomi, Universitas Pamulang
}

\begin{abstract}
Abstrak
Kondisi perekonomian secara keseluruhan mengalami guncangan yang sangat hebat dengan adanya penyebaran Virus Covid-19 ini. Kondisi seperti ini membuat kita harus lebih kreatif untuk menyokong kehidupan keseharian. Untuk itu maka masyarakat perlu untuk diberikan motivasi dan penyuluhan yang benar tentang kewirausahaan. Wirausaha akan dianggap menyenangkan tentu apabila telah memetik hasil dan pada akhirnya hasil itu mampu digunakan sebaik mungkin. Bukan saja sebagai bekal bersenang-senang, namun lebih itu adalah guna mengembangkan bidang wirausaha yang dijalani. Diharapkan dengan dilakukan kegiatan Pengabdian Kepada Masyarakat Rangkapan Jaya Baru, Limo Depok dapat memberikan ide wirausaha yang dapat dilakukan sebagai alternative pendapatan terutama disaat pandemic ini dengan semangat jika wirausaha adalah kegiatan yang menyenangkan dan menguntungkan. Selain itu dapat memberikan gambaran hal apa yang perlu dipersiapkan saat akan memulai suatu kegiatan wirausaha.
\end{abstract}

Kata Kunci : Wirausaha, Bisnis Online, UMKM

\begin{abstract}
The overall economic condition experienced a very great shock with the spread of the Covid-19 Virus. Conditions like this make us have to be more creative to support our daily life. For that, the community needs to be given the right motivation and counseling about entrepreneurship. Entrepreneurship will certainly be considered fun if you have reaped the results and in the end the results can be used as well as possible. Not only as a provision for fun, but more so to develop the entrepreneurial field that is being undertaken. It is hoped that with the Rangkap Jaya Baru Community Service activity, Limo Depok can provide entrepreneurial ideas that can be done as an alternative income, especially during this pandemic with enthusiasm if entrepreneurship is a fun and profitable activity. In addition, it can provide an overview of what needs to be prepared when starting an entrepreneurial activity.
\end{abstract}

Keywords: Entrepreneurship; Online Business: UMKM 


\section{PENDAHULUAN}

Covid-19 mulai merebak pada Desember 2019 di Wuhan China. Virus yang sangat mematikan ini tidak hanya menyerang negeri tirai besi tersebut tetapi juga merambah ke seluruh pelosok dunia termasuk Indonesia. Untuk mengurangi penyebaran virus yang sangat mematikan ini segala upaya dilakukan oleh berbagai Negara, salah satunya adalah dengan melakukan lockdown. Sementara itu di Indonesia tidak melakukan lockdown seperti yang dilakukan dinegara-negara lainnya. Kita menggunakan istilah PSBB (Pembatasan Sosial Berskala Besar). PSBB yang diterapkan di Indonesia tentu saja dengan memperhatikan tingkat kehidupan perekonomian yang ada di masyarakat dimana pekerja kita merupakan pekerja/buruh harian.

Keadaan ini sangat berimbas pada perekonomian masyarakat. Kondisi perekonomian secara keseluruhan mengalami guncangan yang sangat hebat dengan adanya penyebaran Virus Covid-19 ini. Kondisi seperti ini membuat kita harus lebih kreatif untuk menyokong kehidupan keseharian. Untuk itu maka masyarakat perlu untuk diberikan motivasi dan penyuluhan yang benar tentang kewirausahaan.

Wirausaha akan dianggap menyenangkan tentu apabila telah memetik hasil dan pada akhirnya hasil itu mampu digunakan sebaik mungkin. Bukan saja sebagai bekal bersenang-senang, namun lebih itu adalah guna mengembangkan bidang wirausaha yang dijalani. Setiap entrepreneur memiliki cerita yang berbeda-beda mengenai alasan memutuskan untuk memulai sebuah bisnis. Ada yang alasannya adalah tentang keinginan bekerja untuk diri sendiri, ada pula yang beralasan hendak mewujudkan ide-ide kreatif yang acap muncul tanpa intervensi pimpinan kantor tempat mereka bekerja. Namun lebih dari itu, terdapatnya kesepakatan mengenai satu hal, yaitu bahwa wirausaha itu menyenangkan. Alasan Apa yang Menjadikan Wirausaha itu Menyenangkan?

Tak sedikit alasan yang dijadikan indikator perihal menyenangkan menjadi seorang wirausahawan pun pelaku bisnis tersebut. Terdapat beberapa alasan yang semoga bisa dijadikan sumber inspirasi dalam menapaki dunia wirausaha. Menurut Hendro (2011) ada beberapa faktor yang menyebabkan wirausaha berhasil adalah:

1). Faktor peluang

2). Faktor SDM

3). Faktor Keuangan

4). Faktor Organisasional

5). Faktor Perencanaan

6). Faktor Pengelolaan usaha

7). Faktor Pemasaran dan Penjualan

8). Faktor Administrasi

9). Faktor Peraturan pemerintah, Politik, Sosial dan Budaya Lokal

10). Catatan Bisnis

Dengan memperhatikan faktor-faktor tersebut maka diharapkan kewirausahaan dapat berjalan dengan lancar dan mendapatkan hasil yang maksimal.

Berdasarkan uraian di atas maka kami sebagai dosen Universitas Pamulang berkewajiban untuk melaksanakan Pengabdian Kepada Masyarakat (salah satu dari Tri Dharma Perguruan Tinggi) dan dalam hal ini kami akan melaksanakan pengabdian kepada masyarakat dengan tema "WIRAUSAHA ITU MENGUNTUNGKAN DAN MENYENANGKAN?" 


\section{METODE PELAKSANAAN}

Dalam proses kegiatan pengabdian masyarakat ini metodenya berupa seminar dimana narasumber akan berinteraksi dengan pada peserta, agar semua yang hadir merasakan manfaat langsung dan mendapatkan wawasan alasan mengapa wirausaha merupakan kegiatan yang menyenangkan dan dapat mendatangkan keuntungan. Dan diberikan tips bagaimana mengawali suatu kegiatan wirausaha. Pelaksanaan kegiatan PKM ini dilakukan secara offline dengan peserta yang hadir di lokasi dan peserta yang hadir secara online melalui google meet. Setelah penyampaian materi dilanjutkan sesi tanya jawab untuk memberikan tips terkait dengan permasalahan dan pertanyaan yang disampaikan oleh peserta.

\section{HASIL DAN PEMBAHASAN}

Wirausaha berasal dari dua suku kata, wira dan usaha. Wira mempunyai arti sebagai pejuang, pahlawan, berbudi luhur, manusia unggul, berwatak agung dan gagah berani. Di lain sisi, usaha merupakan sebuah perbuatan atau amalan, berbuat sesuatu dan bekerja. Oleh karena itu, secara harfiah makna dari wirausaha adalah sebuah pejuang dalam melakukan suatu pekerjaan. Menurut Kamus Besar Bahasa Indonesia (KBBI), wirausaha merupakan orang yang pandai atau berbakat dalam memahami produk baru, menentukan cara produksi baru, menyusun operasi untuk mengadakan produk baru hingga mengatur permodalan dan pemasarannya. Menurut Kasmir, Wirausaha ialah seorang yang berjiwa pemberani yang berani mengambil resiko untuk membuka sebuah usaha di berbagai kesempatan yang ada.

Sasaran dalam kegiatan pengabdian masyarakat pada kesempatan ini adalah memberikan manfaat bagi masyarakat RT02/04, Rangkapan Jaya Baru, Limo Depok Kegiatan ini diharapkan memberikan manfaat langsung kepada masyarakat di lingkungan RT 02/04, Limo Depok dalam membantu keuangan rumah tangga dengan cara melakukan wirausaha. Diharapkan dengan dilakukan kegiatan PKM mengenai Kewirausahaan dapat memberikan motivasi sekaligus membagikan ilmu bahwa wirausaha adalah sesuatu yang mudah dan menyenangkan. Dimana wirausaha bisa dilakukan dari lingkungan terdekat dengan memperhatikan kebutuhan dari masyarakat sekitar dan tidak lupa melihat pesaing yang ada. Dengan pengetahuan ini diharapkan masyarakat RT02/04, Rangkapan jaya Baru, Limo Depok menjadi lebih terbuka akan peluang yang dapat dihasilkan dari wirausaha ini.

Dalam materi disampaikan motivasi kepada peserta kegiatan PKM yaitu masyarakat RT02/04, Rangkapan Jaya Baru, Limo Depok dengan memberikan alasan mengapa usaha tersebut menyenangkan :

1). Kontrol Penuh

Menuangkan ide dan mengambil keputusan bisa dilakukan sendiri tanpa harus menunggu keputusan bos/pimpinan. Namun ada yang harus diingat, bahwa hal ini perlu tanggung jawab yang besar, karena berhasil atau gagalnya sebuah usaha harus ditanggung sendiri.

2). Tanpa Seragam

Ketika masih kerja kantoran biasanya akan ada 'dress code' berupa seragam atau ketentuan bagaimana cara berpakaian. Namun bila menjalankan usaha 
sendiri, peraturan 'dress code' tersebut bisa diabaikan. Sebagai bos bagi diri sendiri - bebas saja hendak mengenakan pakaian apa saja

3). Go for it

Punya ide untuk meningkatkan keuntungan? Kenapa tidak segera diwujudkan? Lakukan sekarang juga. Go for it!

4). AntiBosanClub

Rasa bocan akan muncul bila melakukan rutinitas yang sama secara terus-menerus. Namun, dengan menjadi seorang wirausahawan, rasa bosan itu bisa diminimalisir atau malah hilang sama sekali. Akan ada banyak sekali to-dolist menarik dan menantang yang bisa dikerjakan.

5). Bebas Traveling

Dengan kemajuan teknologi, seorang penguasana bisa memantau kinerja karyawan menggunakan fasilitas internet. Berlibur di hari kerja, lakukan saja dengan segera!

6). Tak Ada Batasan Usia

Menjadi seorang entrepreneur bisa dimulai setelah lulus kuliah, setelah resign dari pekerjaan, atau malah saat usia 9 tahun. Tak ada batasan usia untuk memulai sebuah usaha. Jangan takut terlalu cepat atau terlalu muda untuk memulai sebuah usaha.

7). Pembukuan Keuangan

Memiliki usaha sendiri berarti harus memahami bahwa pembukuan keuangan itu mutlak diperlukan. Pencatatan segala transaksi keuangan bisa dilakukan dengan dua cara: manual dan daring (online). Pencatatan keuangan manual dikerjakan dengan mencatat di buku khusus. Sementara pembukuan keuangan online dikerjakan dengan mengakses aplikasi keuangan dalam jaringan internet.

8). Make Something from Nothing

Setiap usaha dimulai dari sebuah ide. Sila memunculkan ide apa saja untuk dieksekusi. Jangan pernah merasa terbatas atau terkekang saat brainstorming.

9). Banyak Waktu untuk Keluarga

Menjalankan bisnis milik sendiri artinya bisa fleksibel dalam mengatur waktu. Ketika sebelumnya seolah tak pernah ada waktu untuk keluarga, kini alokasikan cukup dan atau lebih waktu untuk mengantar dan menjemput anak sekolah, berlibur bersama keluarga, dan hal menyenangkan lainnya.

Dalam materi juga disampaikan bagaimana tips awal untuk memulai kegiatan wirausaha yaitu :

1). Siapa target market Anda

Bagaimana melakukan mapping semua informasi yang terkait dengan bisnis yang sedang dijalankan, seperti partner, aktivitas, pesaing, biaya, nilai produk yang dijual

2). Siapa kompetitor Anda

Bagaimana mengenal pesaing produk kita dengan mengkategorikan pesaing tersebut menjadi pesaing terlama, pesaing dengan nilai unik, pesaing terkuat, pesaing terdekat. Sehingga dengan mengenali pesaing produk kita, dapat melakukan strategi yang tepat. Karena dengan pesaing tidak selalu berakhir dengan kompetisi tapi bisa bekerja sama untuk mempromosikan produk, belajar hal-hal unik dari pesaing kita, mengisi pasar yang belum ada pesaingnya.

3). Apa Value Bisnis / Produk Anda

Disampaikan pengertian nilai / value adalah harga ditambah dengan nilai tambah yang bisa diberikan kepada konsumen sehingga harga yang diberikan dapat lebih 
menguntungkan bagi penjualnnya. Seperti produk yang dijual dalam kaitan kuliner sehat, sedekah nasi kotak, produk Ikea yang dikemas denagn nilai arsitek sehingga semua produk tersebut dapat dijual di atas rata-rata produk yang sejenisnya.

\section{SIMPULAN}

Diharapkan dengan dilakukan kegiatan Pengabdian Kepada Masyarakat RT02/04, Rangkapan Jaya Baru, Limo Depok dapat memberikan ide wirausaha yang dapat dilakukan sebagai alternative pendapatan terutama disaat pandemic ini dengan semangat jika wirausaha adalah kegiatan yang menyenangkan dan menguntungkan. Selain itu dapat memberikan gambaran hal apa yang perlu dipersiapkan saat akan memulai suatu kegiatan wirausaha.

\section{DAFTAR PUSTAKA}

Alma. B, (2007). Kewirausahaan. Bandung: Alfabeta.

Andriani, J., Wulansari, R., Sampurnaningsih, S. R., \& Susanti, N. (2020). Membentuk Enterpreneur Generasi Muda Untuk Membangun Percaya Diri Dalam Menghadapi Tantangan Masa Depan Pada Yayasan Ishlahul Hayat Rumah Yatim \& Dhuafa Keluarahan Bambu Apus Kecamatan Pamulang Tangerang Selatan. Jurnal Lokabmas Kreatif, 1(3), 7-15.

Ananda, A. D. (2018). Pengembangan Usaha Mikro Kecil Dan Menengah (UMKM) Berbasis Ekonomi Kreatif Di Kota Malang. Doctoral dissertation, University of Muhammadiyah Malang.

Azhar, S. (2008). Sikap Manusia Teori dan Pengukurannya, Yogyakarta: Pustaka Usaha. Budiati, Y., Yani, T. E., \& Universari, N. (2012). Minat Mahasiswa Menjadi Wirausaha (Studi Pada Mahasiswa Fakultas Ekonomi Universitas Semarang). Jurnal dinamika sosbud, 14(1), 89-100.

Gerungan, W.A. (2007). Psikologi Sosial : Suatu Pengantar. Jakarta: PT Eresko.

Gunartin, G. (2019). Analisa Efektivitas Bank Sampah sebagai Alternatif Pengelolaan Sampah Dalam Upaya Menuju Smart City di Kota Tangerang Selatan. INOVASI, 6(1), 1-6.

Husna, N., Yuhelmi, Y., \& Trianita, M. (2015). Pengaruh Kepribadian dan Mata Kuliah Kewirausahaan terhadap Intensi Berwirausaha Pada Mahasiswa Penerima Dana Program Mahasiswa Wirausaha (PMW) di Fakultas Ekonomi Universitas Bung Hatta. Jurnal Apresiasi Ekonomi, 3(3), 167-171.

Kamil, M. (2007). Pendidikan dan Pelatihan (Konsep dan Aplikasi). Bandung: Alfabeta.

Kurniawan, A., Khafid, M., \& Pujiati, A. (2016). Pengaruh lingkungan keluarga, motivasi, dan kepribadian terhadap minat wirausaha melalui self efficacy. Journal of Economic Education, 5(1), 100-109.

Majdi, M. Z. (2012). Pengaruh Pembelajaran Kewirausahaan, Internalisasi Nilai Kewirausahaan di Keluarga dan Motivasi Minat Berwirausaha. Educatio, 7(2), 115. 
Rahmanita, F., Andriani, J., \& Manik, C. D. (2020). Membangun Generasi Milenial yang Cinta Tanah Air Melalui Potensi Profesi dan Wirausaha. Jurnal Loyalitas Sosial: Journal of Community Service in Humanities and Social Sciences, 2(1), 25-36.

Sudjana, D. (2004) Pendidikan Nonformal, Wawasan, Sejarah Perkembangan, Falsafah, Teori Pendukung, Asas. Bandung: Falah Production.

Suryana. (2007). Kewirausahaan, Pedoman Praktis Kiat dan Proses Menuju Sukses. Jakarta: Salemba Empat.

Utama, D. D. T., \& DARWANTO, D. (2013). Pengembangan Usaha Mikro Kecil dan Menengah (UMKM) Berbasis Ekonomi Kreatif di Kota Semarang (Doctoral dissertation, Fakultas Ekonomika dan Bisnis).

Winarto, (2004). First Step to Be An Entrepreneur. Jakarta. Elex Media Komputindo.

Yanti, P. E. D., Nuridja, I. M., \& Dunia, I. K. (2014). Pengaruh lingkungan keluarga terhadap berwirausaha siswa kelas xi smk negeri 1 singaraja. Skripsi (tidak diterbitkan). Singaraja: Universitas Pendidikan Ganesta. 